25 Smithburn, K. C. (1949). Brit. J. exp. Path., 30, 1.

Theiler, M. (1951). The Development of Vaccines Against Yellow Fever (Nobel Prize, 1951). Norstedt, Stockholm. 1952.

(1952). Viral and Rickettsial Infections of Man, edited by Thos. M. Rivers, 2nd ed., p. 531 . Lippincott, Philadelphia.

18 (1930). Science, 71, 367 .

- Peltier, M., Durieux, C., Jonchere, H., and Arquie, E. (1940). Ann. Inst. Pastcur, 65, 146

(1946). Epidem. Inform. Bull., 2, 806.

21 Theiler, M., and Smith, H. H. (1937). J. exp. Med., 65, 767.

- (1951). Yellow Fever, edited by George K. Strode, D. 105

McGraw-Hill Book Company, New York.

Fox, J. P., Kossobudzki, S. L., and da Cunha, J. F. (1943). Amer. J. Hy8., 38, 113.

Dick, G. W. A., and Gee, F. L. (1952). Trans. roy. Soc. Trop. Med. Hy8., 46, 449.

9s Hahn, R. G. (1951). Amer. J. Hyg., 54, 50.

36 Pasteur, L., Chamberland, and Roux (1884). C.R. Acad. Sct., Paris, 98 457.

It Leach, C. N., and Johnson, H. N. (1940). Amer. J. trop. Med., 20,

ss Cox, H. R. (1953). Proc. 57th Annual Meeting U.S. Livestock San. Ass., p. 305.

Personal communication.

80 Koprowski, H., and Cox, H. R. (1948). J. Immunol, 60, 533

31 (1948). Proc. Soc. exp. Biol., N.Y., 68, 612.

32 - (1952). Vet. Med., 47, 144, 154.

Kaplan. M. M.. Recent Progress in the Control of Rabies in Animals. Bull. Wld Hith Org. In press.

24 Tierkel. E. S., and Kaplan, M. M. (1953). Preliminary report made at

15 th Int. Congr. Vet. Med.. Stockholm, Sweden (August).

$2 s$ Steele, J. H. (1953). Vet. Med., 48, 425 .

36 Koprowski, H., and Black, J. (1954), J. Immunol., 72, 85.

27 Hardy, W. T., and Price, D. A. (1952). J. Amer. vet. med. Ass., 120 23.

38 McGowan, B. (1953). Cornell Vet., 43, 213.

McKercher, D. G., McGowan, B., Howarth, J. A., and Saito, J. K. 1953.) J. Amer. vet. med. Ass., 122, 300.

do Alexander, R. A. (1953). Personal communication.

"1 Cox, H. R. "Bluetongue Virus," Bact. Rev. In press.

2 Mason, J. H., Coles, J. D. W. A., and Alexander, R. A. (1940)

4s Alexander, R. A. (1947). Onderstepoort J. vet. Sci., 22, 7

- Neitz, W. O. Adelaar. T, F, and Haig. D. A. (1947). J. Sth Afr. vet. med. Ass., 18. 51 .

cs - Haig, D. A., and Adelaar, T. F. (1947). Onderstepoort J. vet. Sct. 21, 231.

16 (1951). Onderstepoort J. vet. Res., 25, 3

“7 Koprowski, H. (1954). Personal communication.

$\therefore$ Alexander, R. A. (1954). Personal communication.

“Cox, H R. (1953). Lancet, 2,

so Frenkel, H. S., and Frederiks, H. H. J. (1949). Nature, Lond., 164 B1 235. (1949). Amer. J. vet. Res., 10, 142.

82 - Dunne, H. W., and Osteen, O. (1949), J. Amer. vet. med. Ass., 115, 178

"2 Ass., (1951). Amer. J. vet. Res., 12. 187

$\because$ and Dunne, H. W. (1952). Ibid.. 13, 21

6s Enders, J. F., Weller, T. H., and Robbins, F. C. (1949). Science, 109

so Robbins, F. C., Weller, T. H., and Enders, J. F. (1952). J. Immunol.

57 Youngner, J. S., Ward, E. N., and Salk, J. E. (1952). Amer. J. Hyg.

$55,291$.

so 5 , (1952). Ibid., 55, 301.

${ }^{80}$ - Lewis, L. J., Ward, E. N., and Salk, J. E. (1952). Ibid., 55, 347 o Ledinko. N., Riordan, J. T., and Melnick, J. L. (1951). Proc. Soc. exp. Biol., N.Y.. 78, 83.

${ }^{81}$ - and Melnick, J. L. (1952). Ibid., 81, 144

82 Melnick, J. L., and Riordan, J. T. (1952). Ibid., 81, 208.

os Ledinko, N., Riordan, J. T., and Melnick, J. L. (1952). Amer. J. Hyg. $55,323$.

64 Riordan, J. T., Ledinko, N., and Melnick, J. L. (1952). Ibid., 55, 339

os Syverton, J. T., Scherer, W. F., and Butorac, G. (1951). Proc. Soc. exp. Biol., N.Y., 77, 23.

66 - (1952). J. exp. Med. 96, 355.

it Scherer, W. F., and Syverton, J. T. (1952). Ibid., 96, 369.

${ }^{8}$ - (1952). Ibid., 96, 389.

Bo - - and Gey, G. O. (1953). Ibid. 97, 695.

io Franklin, A. E., Duncan, D., Wood, W., and Rhodes, A. J. (1952) Proc. Soc. exp. Biol., N.Y.. 79, 715.

71 Thicke, J. C.. Duncan, D., Wood, W.. Pranklin, A. E., and Rhodes, A. J. (1952). Canad. J. med. Sci., 30, 231.

is Wood. W. Franklin, A. E., Clark, E. M., Duncan, D., and Rhodes, A. J. (1952). Proc. Soc. exp. Biol., N.Y., 81, 434.

is Smith. W. M. Chambers, V. C., and Evans, C. A. (1950). Northwest.

74 Med., 49, 368. (1951). Proc. Soc. exp. Biol., N.Y., 76, 696.

is Salk, J. E. (1953). J. Amer. med. Ass., 151, 1081.

18 Cox, H. R. Unpublished data.

17 Li, C. P., and Schaeffer, M. (1953). Proc. Soc. exp. Biol., N.Y., 82, 477.

${ }^{3}$ Sabin, A. B. (1953). Amer. J. Dis. Child., 86, 301.

so Rox, H. R. (1953). Bull. N.Y. Acad. Med., 29, 943. Roca-Garcia, M.. Moyer,

exp. Biol.. N.Y., 81, 519. Cox, H. R. (1952). Ibid., 81, 525.

2 Moyer. A. W. Accorti, C., and Cox, H. R. (1952). Ibid., 81, 513

ss Roca-Garcia, M. (1954) Personal communication.

The Annals of Eugenics, which was founded by Karl Pearson in 1925, has now changed its title to Annals of Human Genetics. The numbering of volumes remains unaltered. The journal is edited by Professor L. S. Penrose, F.R.S., and published by the Cambridge University Press.

\section{THE DIAGNOSIS AND TREATMENT OF HYPOPITUITARISM}

\author{
BY \\ S. R. F. WHITTAKER, M.D., F.R.C.P. \\ Physician, Warwick Hospital \\ AND

\section{T. P. WHITEHEAD, F.R.I.C. \\ Biochemist, Warwick Hospital}

During the past three years we have studied nine cases of hypopituitarism and endeavoured to find a satisfactory scheme of treatment using A.C.T.H. and cortisone in addition to preparations of the thyroid gland and testosterone. In the course of this investigation we have been struck by the distressingly long period, sometimes extending over a number of years, that may elapse between the onset of symptoms and the establishment of the diagnosis. Despite the classic papers of Sheehan and his associates (Sheehan, 1939; Sheehan and Summers, 1949 ; Cooke and Sheehan, 1950), it appears that the syndrome of hypopituitarism may still pass unrecognized for a considerable time after the patient has sought medical aid, possibly owing to the confusing variation in the impairment of function of the thyroid gland, the adrenal cortex, and the gonads that may exist in different patients.

Since the treatment of hypopituitarism with A.C.T.H. and cortisone promises to be a considerable advance on previous methods, an early diagnosis assumes more importance, and we feel it worth while to record some observations on the clinical picture, a brief account of the investigations likely to be of value in establishing the diagnosis, and the results of treatment with A.C.T.H. and cortisone, sometimes combined with other hormones, for periods up to two years.

Material.-This study is based on seven women and two men whose ages ranged from 32 to 63 years, with an average of 47 . Five of the women (Cases 1-5) had suffered from severe haemorrhage after childbirth, and a post-partum necrosis of the pituitary gland was likely. The exact nature of the pathological process damaging the pituitary gland is unknown in the other four cases, although one patient had been treated for syphilis some years previously (Case 9). One patient died during the course of the investigation (Case 1).

\section{Clinical Picture}

The difficulties of an early diagnosis are perhaps illustrated by the fact that nine patients between them paid over 30 visits to different hospitals or hospital departments before the diagnosis of hypopituitarism was finally made. The average duration of symptoms was over 10 years, and, unless there was a clear history of haemorrhage during childbirth followed by absence of lactation and scanty periods or amenorrhoea, it was difficult to determine accurately the date of onset of the disease. The clinical picture varied from patient to patient, but the following features were the most constant.

Tiredness.-All patients complained of feeling tired, and it was usually this symptom that first prompted them to visit a doctor. A diagnosis of anaemia was often made, and some tonic prescribed. The tiredness continued but rarely became incapacitating, and after a time these patients became accustomed to feeling tired and struggled on as best they could, aware that there was something the matter 
with them but disappointed by repeated visits to doctors or hospitals. The disease is essentially a chronic one, and several patients stated that they had almost forgotten what it was like to feel well.

Mental State.-Some degree of mental inertia was noted in all patients, and the blunting of the mental faculties appears to compensate for the discomforts caused by other features of the disease and the placid acceptance of ineffective treatment over a number of years. There was, however, a considerable variation in the degree of mental change. One patient had been admitted to a mental hospital (Case 4), whereas another was still managing a thriving business despite the fact that he had had symptoms of hypopituitarism for 12 years (Case 9). Between these extremes four patients were carrying out household duties (Cases 1, 2, 6, and 7) and three were chronic invalids being cared for by relatives (Cases 3, 5, and 8).

Sensitivity to Cold.-All patients complained of feeling cold even in summer weather, and it was noticed that some of them arrived at the out-patient department wearing too many clothes for the season of the year. When admitted to hospital they lay in bed under numerous blankets with only a small area of the face showing, and one brought with him a nightcap which he had worn for a number of years. Erythema ab igne was a common finding in women patients, although the areas were not pigmented.

Loss of Libido.-Hubble (1952) pointed out that the sex hormones are the first to be affected in hypopituitarism and may antedate clinical evidence of failure of the thyroid gland or the adrenal cortex by as long a period as 20 years. It is unfortunate that there is a natural reluctance to inquire into a patient's sexual life, although Sheehan and Summers (1949) noted that female patients suffering from hypopituitarism lose their normal bashfulness, an observation which we can readily confirm. Loss of libido is an important early symptom, and both male patients were impotent. Female patients who continued intercourse as part of their marital duties derived little, if any, pleasure from it and rarely obtained an orgasm.

Amenorrhoea.-Complete amenorrhoea was noted in five women but had been of gradual onset in three. One woman had normal periods and became pregnant two years after a clinical diagnosis of hypopituitarism (made by Dr. C. R. St. Johnston) had been confirmed by numerous investigations (Case 3). The pregnancy went to full term, but subsequently no improvement in her condition was noted, and her periods began again in a normal manner. Such incidents, although exceptionally rare, are mentioned by Sheehan and Murdoch (1938).

Loss of Hair.-One female patient (Case 6) lost all the pubic and axillary hairs at the age of 19 but never thought to mention the fact to any of the practitioners whom she consulted during the next 20 years. In general, patients are reluctant to admit the loss of hair on any part of the body, and neither of the male patients volunteered the information that they had stopped shaving some time previously. The loss of pubic hair may not be complete, but nevertheless it was striking enough to call for comment in all our patients. and served as a useful pointer to the diagnosis of hypopituitarism.

Appearance.-The lack of animation of the face, the waxy pallor and slight puffiness of the skin, and the thinning of the eyebrows and of the hair on the head combine to give an appearance which looks grotesque in young and middleaged patients and is easily recognizable. In older patients a closer inspection may be necessary, since the contrast with other patients of the same age group is less obvious. The loss of skin pigment is widespread and the areolae of the breasts should be inspected. Familiarity with the facies of hypopituitarism is a considerable aid in the clinical diagnosis, but such familiarity may be difficult to acquire, as the disease is not common and our experience of successive house-physicians suggests that some medical students may complete their hospital training without an opportunity of observing a case. The skin is dry owing to the absence of sweating, and feels smooth and soft. As Sheehan and Summers (1949) have emphasized, patients suffering from hypopituitarism are not emaciated, and three patients in the present series had a rather plump appearance. The body weights of the remaining six were also within the normal range for their height and age.

Speech.-A slow soft monotonous type of speech was noted in six patients, but in the other three no special comment could be made, although their speech became more articulate after treatment. The slowness of the speech appeared to be related to the degree of mental lethargy, and two patients were apt to tail off in the middle of a sentence as if they had not enough mental energy to complete it (Cases 4 and 8 ).

Routine examination of the various systems added little to the clinical picture. The pulse rate varied from 62 to 80 a minute, with an average rate of 70 . The systolic blood pressure ranged from 90 to $155 \mathrm{~mm}$. $\mathrm{Hg}$, with a mean of $115 \mathrm{~mm}$. A low-voltage electrocardiogram with rather flat $T$ waves was recorded in six cases and a normal electrocardiogram in three. A mild degree of normochromic anaemia was common, but was less than might have been expected from the appearance of the patient. The haemoglobin varied from 62 to $101 \%$, with a mean of $83 \%$.

\section{Biochemical Investigation of Hypopituitarism}

Sheehan and Summers (1949) stated that a confident diagnosis of complete hypopituitarism could usually be made from a short clinical examination. They considered that in severe cases the biochemical tests were chiefly of academic interest and for assessment of the severity of the disease. In mild cases the diagnosis could be very uncertain. Fraser and Smith (1941) thought that mild cases of hypopituitarism might be confused with other cachexias, and biochemical confirmation was usually required. They advocated the use of the insulin-tolerance test and the estimation of urinary 17-ketosteroids as aids in the diagnosis of hypopituitarism. Oelbaum (1952), in a study of six cases of hypopituitarism from post-partum necrosis, concluded that biochemical investigations in hypopituitarism are not of great assistance in diagnosis as they are positive only when the clinical diagnosis is already obvious, at least to the initiated.

Table I shows the biochemical investigations carried out on our patients. It will be seen that there is a high proportion of abnormal results, particularly in the basal meta-

TABLE I.-Biochemical Investigations

\begin{tabular}{|c|c|c|c|c|c|c|c|c|c|}
\hline Case: & 1 & 2 & 3 & 4 & 5 & 6 & 7 & 8 & 9 \\
\hline $\begin{array}{l}\text { Sex } \quad \ldots \\
\text { Age (in years) } \quad \ldots \\
\text { Duration of symptoms (in }\end{array}$ & $\underset{32}{F}$ & $\begin{array}{c}F \\
38\end{array}$ & $\begin{array}{l}F \\
41\end{array}$ & $\underset{40}{F}$ & $\begin{array}{c}F \\
56\end{array}$ & $\underset{52}{F}$ & $\begin{array}{c}F \\
63\end{array}$ & $\begin{array}{l}M \\
50\end{array}$ & $\begin{array}{l}\mathrm{M} \\
52\end{array}$ \\
\hline $\begin{array}{lll}\text { years) } & \ldots & \cdots\end{array}$ & $\begin{array}{c}11 \\
43 \\
\text { Pos. }\end{array}$ & $\mid \begin{array}{c}10 \\
-43 \\
\text { Pos. }\end{array}$ & $\begin{array}{c}7 \\
-40 \\
\text { Pos. }\end{array}$ & $\begin{array}{c}11 \\
29 \\
\text { Normal }\end{array}$ & $\begin{array}{l}26 \\
-17 \\
-\end{array}$ & $\begin{array}{c}33 \\
35 \\
\text { Pos. }\end{array}$ & $\mid \begin{array}{c}10 \\
-36 \\
\text { Pos. }\end{array}$ & \begin{tabular}{|c|}
4 \\
-40 \\
Pos.
\end{tabular} & $\begin{array}{c}12 \\
-33 \\
\text { Pos. }\end{array}$ \\
\hline $\begin{array}{lll}\text { mg. day } & \ldots & \ldots \\
\text { Kepler test } . & \ldots & \\
\text { Fasting blood sugar (mg./ }\end{array}$ & $\begin{array}{c}2 \cdot 5 \\
\text { Pos. }\end{array}$ & $\begin{array}{c}1.8 \\
\text { Neg. }\end{array}$ & $\begin{array}{l}\text { Nil } \\
\text { Pos. }\end{array}$ & $\begin{array}{c}1 \cdot 2 \\
\text { Pos. }\end{array}$ & 0.1 & $\begin{array}{l}0.7 \\
\text { Pos. }\end{array}$ & $\begin{array}{c}\text { Nil } \\
\text { Pos. }\end{array}$ & $\mid \begin{array}{c}0 \cdot 1 \\
\text { Pos. }\end{array}$ & $\begin{array}{l}1.8 \\
\text { Pos. }\end{array}$ \\
\hline $\begin{array}{l}100 \mathrm{ml} .) \\
\text { Cholesterol (mg./100 ml.) } \\
\text { Serum sodium (mEq/1.) } \\
\text { Serum potassium }(\mathrm{mEq} / \mathrm{l} .) \\
\text { Serum chloride }(\mathrm{mEq} / \mathrm{l} .)\end{array}$ & $\begin{array}{c}71 \\
325 \\
131 \\
5 \cdot 0 \\
98\end{array}$ & \begin{tabular}{|c|}
79 \\
533 \\
143 \\
$5 \cdot 3$ \\
107
\end{tabular} & $\begin{array}{l}68 \\
420 \\
137 \\
4 \cdot 6 \\
102\end{array}$ & $\begin{array}{l}90 \\
420 \\
115 \\
4 \cdot 3 \\
85\end{array}$ & \begin{tabular}{|c|}
86 \\
450 \\
132 \\
$4 \cdot 3$ \\
94
\end{tabular} & $\begin{array}{c}95 \\
248 \\
136 \\
4 \cdot 2 \\
104\end{array}$ & $\begin{array}{c}72 \\
190 \\
140 \\
5.0 \\
106\end{array}$ & $\begin{array}{l}91 \\
200 \\
135 \\
4 \cdot 6 \\
105\end{array}$ & $\begin{array}{c}83 \\
287 \\
129 \\
4 \cdot 4 \\
92\end{array}$ \\
\hline
\end{tabular}

bolic rate, the urinary $17-$ ketosteroids, the insulin-tolerance test, and the Kepler test. This prompted us to inquire further into the usefulness of these tests in the diagnosis of hypopituitarism.

We have collected the biochemical results in the 51 cases abstracted from the literature and included our nine cases to make a total of 60 . All the cases from the literature have been published in the last 12 years-the majority of them chiefly in British journals in the last four years; the cases abstracted were those with an adequate history and with reasonably full biochemical investigation.

Of the 60 cases, 37 followed severe post-partum haemorrhage, 7 resulted from tumour, and 16 were of unknown 
or doubtful aetiology. The age at diagnosis ranged from 19 to 64 years and their history varied from three months to thirty-six years with an average of eleven years. There were 45 females and 15 males. In the investigation of these 60 cases the three biochemical tests most frequently chosen out of a number of tests of pituitary function were the basal metabolic rate, insulin-tolerance, and urinary 17-ketosteroids.

In Table II these tests are treated individually, and the number of cases in which the test was used and the number of cases in which the test was abnormal are recorded. In each of the tests between 85 and $90 \%$ of the cases tested gave abnormal results.

TABLB II

\begin{tabular}{|c|c|c|}
\hline Test & $\begin{array}{l}\text { No. of } \\
\text { Cases } \\
\text { Tested }\end{array}$ & $\begin{array}{l}\text { No. of } \\
\text { Abnormal } \\
\text { Cases }\end{array}$ \\
\hline $\begin{array}{l}\text { B.M.R. (abnormal if less than }-10 \% \text { of normal) } \\
\text { 17-ketosteroids (abnormal if less than } 2 \text { mg./day) } \\
\text { Insulin tolerance (interpretation as by Fraser and }\end{array}$ & $\begin{array}{l}54 \\
54\end{array}$ & 48 \\
\hline Smith, 1941) $\ldots$.. & 45 & 38 \\
\hline
\end{tabular}

Table III shows the results obtained with a combination of all these tests. It will be seen that two out of three tests have proved abnormal in 37 out of $\mathbf{4 0}$ cases of hypopituitarism reported during the past few years, and their

TABLE III

\begin{tabular}{c|c|c|c|c}
\hline $\begin{array}{c}\text { Total No. } \\
\text { Investigated }\end{array}$ & $\begin{array}{c}\text { No. with All } \\
\text { Three Tests } \\
\text { Abnormal }\end{array}$ & $\begin{array}{c}\text { No. with Only } \\
\text { Two Tests } \\
\text { Abnormal }\end{array}$ & $\begin{array}{c}\text { No. with Only } \\
\text { One Test } \\
\text { Abnormal }\end{array}$ & $\begin{array}{c}\text { No. with } \\
\text { None } \\
\text { Abnormal }\end{array}$ \\
\hline 40 & 30 & 7 & 1 & 2 \\
\hline
\end{tabular}

value in the investigation of suspected cases seems firmly established. From the few but increasing number of cases in which the Kepler test has been performed, and from our own results, it appears that it is a most useful test of adrenal function. The histories of our patients emphasize that the clinical diagnosis is not always obvious even to general physicians or psychiatrists, and we suggest that more use should be made of biochemical tests of pituitary function in cases of general debility or gradual failing of mental powers.

\section{Treatment}

Several favourable reports have recently been published on the treatment of hypopituitarism, usually for short periods, with A.C.T.H. and cortisone (Summers and Sheehan, 1951 ; Robertson and Kirkpatrick, 1951 ; Rolland and Matthews, 1952 ; Hart, 1953; Aber et al., 1954). We first started treating some of our patients with A.C.T.H. and cortisone in the early months of 1951, when supplies were available from the Ministry of Health. The following results are based on three years' experience with these hormones; during this time we have changed from one scheme of treatment to another and, in addition, used preparations of the thyroid gland and methyltestosterone.

\section{A.C.T.H.}

A daily dose of $25-40 \mathrm{mg}$. of A.C.T.H. is a satisfactory form of treatment, and we have had gratifying results in eight patients despite the fact that the Thorn test carried out before treatment did not always suggest that there would be a striking response to A.C.T.H. Within 48 hours of receiving injections all patients became more active both mentally and physically, and experienced a sense of wellbeing which far exceeded any effects caused by A.C.T.H. when given for other conditions. Patients suffering from hypopituitarism begin to take interest in their surroundings, their speech becomes more distinct, blankets are cast off the bed ; and many are the expressions of deep gratitude by them and their relatives.

Unfortunately, the stimulation produced by A.C.T.H. does not last long, and all our patients relapsed to some extent within 10 days of the cessation of injections. After four weeks relapse was complete. In Case 1 treatment was continued for over three months with an average daily dose of $45 \mathrm{mg}$., but a relapse occurred just as quickly as after a shorter course.

We had three unpleasant experiences when we were using doses of 40 or $60 \mathrm{mg}$. of A.C.T.H. daily. We think that each was caused by water retention, and it is probable that the early batches of A.C.T.H. received in this country were contaminated with pitressin, which contributed to the disturbance of water balance. The Chart shows the urinary volume and urinary sodium excretion before and during the first 11 days of treatment of Case 3. Similar biochemical changes were noted in Cases 1 and 2. The urinary sodium and volume increased for the first few days after treatment; this was followed by a sudden fall and then an increase. Over this period of retention followed by diuresis the patient complained of severe headache and looked bloated.

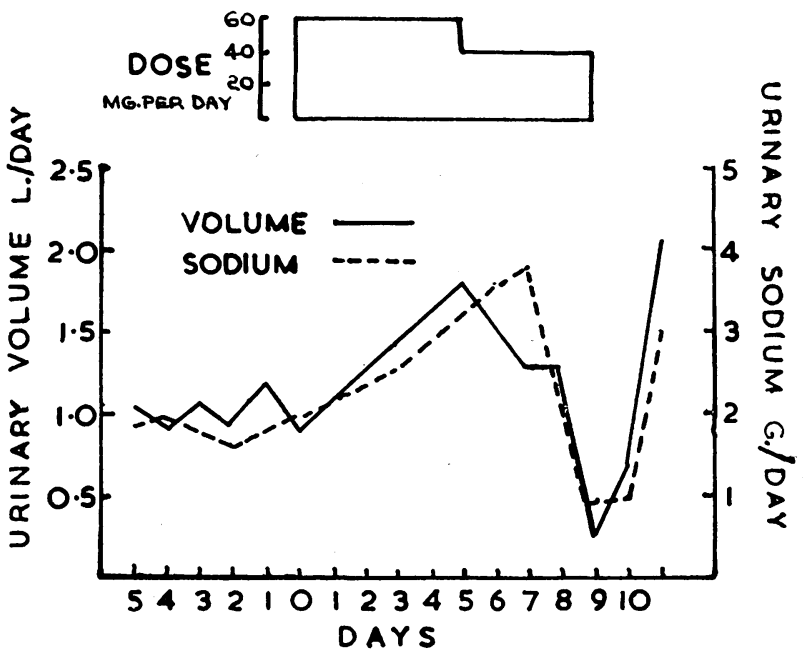

Chart showing the changes of urinary volume and urinary sodium during A.C.T.H. treatment of Case 3.

Cerebration became disordered and Case 1 was stuporous. Recovery from the state of water retention was uneventful after injections of A.C.T.H. had been stopped or the dose reduced, but the experience so frightened Case 2 that this patient refused any further treatment despite her continued ill-health from the disease. Bartter et al. (1950) and Knowlton et al. (1950) reported similar experiences during treatment with A.C.T.H., but we would emphasize that severe water retention is not a common complication and we did not encounter it during the later part of the investigation, when we were using smaller amounts of different batches of A.C.T.H. Nevertheless, we consider that the first course of A.C.T.H. should be given while the patient is in hospital, so that the urinary volume can be checked daily and a careful watch kept for signs of water retention.

We have not treated any patient with A.C.T.H. for longer than eight months, and we have now given up this method in favour of replacement therapy with cortisone and thyroid gland. On the whole, however, A.C.T.H. proved a considerable advance on any treatment we had used in cases of hypopituitarism before A.C.T.H. and cortisone were available, and, provided arrangements can be made to maintain stimulation of the pituitary gland with injections of A.C.T.H. once or twice weekly, there seems to be no reason why satisfactory treatment cannot be continued indefinitely. Aber et al. (1954) report three patients who are being maintained in good health with weekly injections of 40 units of " acthar gel."

\section{Cortisone}

We have treated eight patients with cortisone, given either by intramuscular injection or in tablet form. Treatment started with a daily dose of 50 or $75 \mathrm{mg}$., which was reduced after a few days to a daily maintenance dose of $12.5,25$, 
or $37.5 \mathrm{mg}$. With the exception of Case 5 the immediate results of treatment with cortisone were excellent, and after a few days' treatment all patients showed a striking clinical improvement, which was indistinguishable from that obtained in the same patients with A.C.T.H.

We had an unfortunate experience with Case 5, who drifted into coma while receiving $50 \mathrm{mg}$. of cortisone daily. This lady of 56 years had suffered from hypopituitarism for many years, but there was no history of a previous attack of coma. She had responded well to A.C.T.H., but relapsed completely ten days after injections were discontinued. She was then given $50 \mathrm{mg}$. of cortisone daily, and after three doses appeared to be responding. On the fourth day, however, she became listless, and gradually sank into coma during the next four days, injections of cortisone being continued daily. The blood electrolytes were followed closely, but no significant changes were noted. The serum sodium remained around $138 \mathrm{mEq} / \mathrm{l}$. and the serum potassium 5 $\mathrm{mEq} / \mathrm{l}$. The blood sugar was $160 \mathrm{mg} / 100 \mathrm{ml}$. The striking finding was a gradual fall in the rectal temperature to $87^{\circ} \mathrm{F}$. $\left(30.6^{\circ}\right.$ C.) (measured with a bacteriological thermometer) when she was in coma. Injections of cortisone were stopped, and fortunately she responded well to warmth applied by electric cradles. We believe that the attack of coma was of the myxoedematous type described by Sheehan and Summers (1952), and it is interesting that it should apparently have been precipitated by treatment with cortisone. After recovery this patient was given $25 \mathrm{mg}$. of cortisone together with $\frac{1}{2}$ gr. (32 mg.) of thyroid gland daily, and there have been no further episodes of coma during the 16 months she has now received this treatment.

Cases 3, 4, and 8 were maintained on $25 \mathrm{mg}$. of cortisone daily for periods of three to six months, and during the greater part of that time they were carrying out their normal duties at home and attending hospital at monthly intervals for survey. Although the improvement in their health was most gratifying and they no longer required the assistance of relatives to run their homes, their facies appeared myxoedematous and, indeed, more so than before treatment with cortisone. Re-examination of the basal metabolic rates in Cases 3 and 8 revealed figures of -35 and $-20 \%$. This was obviously not satisfactory, and it seemed likely that further improvement could be effected by adding extract of thyroid gland to the daily dose of cortisone. We have subsequently changed the treatment of all patients who were receiving cortisone alone to a mixture of cortisone and thyroid.

\section{Cortisone and Thyroid Gland}

We have treated seven patients for periods of between nine and twenty months with daily doses of cortisone and thyroid given in tablet form. The daily amounts which each patient was receiving at the time of writing are shown in Table IV.

TABLE IV

\begin{tabular}{|c|c|c|c|}
\hline Case & Cortisone & Thyroideum B.P. & Period of Treatment \\
\hline $\begin{array}{l}3 \\
4 \\
5 \\
6 \\
7 \\
8 \\
9\end{array}$ & $\begin{array}{l}25 \mathrm{mg} . \\
12.5 \mathrm{mg} . \\
25 \mathrm{mg} . \\
12.5 \mathrm{mg} . \\
12.5 \mathrm{mg} . \\
12.5 \mathrm{mg} . \\
25 \mathrm{mg} .\end{array}$ & $\begin{array}{l}1 \text { gr. (65 mg.) } \\
\frac{1}{2} \text { gr. (32 mg.) } \\
\frac{1}{2} \text { gr. (32 mg.) } \\
\left.\frac{1}{\frac{1}{2}} \text { gr. ( } 32 \mathrm{mg} .\right) \\
1 \frac{1}{2} \text { gr. (97 mg.) } \\
1 \frac{1}{2} \text { gr. (97 mg.) } \\
1 \text { gr. (65 mg.) }\end{array}$ & 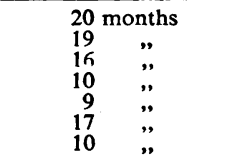 \\
\hline
\end{tabular}

We suggest that treatment should start with a daily dose of $25 \mathrm{mg}$. of cortisone and $\frac{1}{2} \mathrm{gr}$. $(32 \mathrm{mg}$.) thyroid and that these amounts be altered during the first few months of treatment rather by the method of trial and error. Patients suffering from hypopituitarism usually feel so much better after a few doses of cortisone alone that the addition of thyroid may not seem necessary. Nevertheless, we have found that further improvement could be obtained in every case, and we have also reduced the dose of cortisone from $25 \mathrm{mg}$. to $12.5 \mathrm{mg}$. daily in four cases without any deterioration in their condition. So far there have been no com- plications during this form of treatment, which has now been given to seven patients for an average period of fourteen months.

Case 6 had previously suffered from pulmonary tuberculosis, but the radiological changes in both lungs remained stationary, and as cortisone was being given as a replacement the usual qualifications regarding its use for long periods hardly apply. Patients were seen at monthly or two-monthly intervals as out-patients, when adjustments in dosage could be made. Neither the age of the patient nor the length of duration of symptoms appears to preclude an excellent response. Case 5 started treatment at the age of 56, having suffered from symptoms of hypopituitarism for twenty-six years and having been a chronic invalid for several years. She now leads a normal life, carrying out her own housework and occasionally looking after her grandchildren. There can be few more gratifying experiences than the diagnosis and successful treatment of a case of hypopituitarism of many years' standing.

\section{Addition of Testosterone}

We have recently added amounts of methyltestosterone varying from 25 to $50 \mathrm{mg}$. daily to the maintenance dose of cortisone and thyroid in Cases 3, 4, 8, and 9. In both male patients (Cases 8 and 9) there has been an increase in libido and strength of the erection and in the growth of pubic hairs. No effect has been noticed so far by either of the female patients, who were satisfied by the increase in libido caused by cortisone. Case 3 continues to have regular periods but has not conceived again since her pregnancy four years ago.

\section{Water Balance and Coma in Hypopituitarism}

Throughout the whole investigation we have been continually reminded of the abnormality of water balance in hypopituitarism. This has been the subject of several reports, and Slessor (1952) has shown evidence of an increased antidiuretic hormone in the blood of patients with secondary or primary adrenal deficiency. Lewis (1952), however, thinks the abnormality is caused by defective function of the osmoreceptors or of the renal tubules, or to both of these. Prunty (1953) regards both A.C.T.H. and cortisone as having a direct action on water balance, apart from the contamination with pitressin which may occur in some batches of A.C.T.H. Robertson (1951), in one case, found no effect on water metabolism during A.C.T.H. or cortisone therapy. Chalmers and Lewis (1951) and Oleesky and Stanbury (1951) showed normal handling of administered water during cortisone therapy.

Our experience is similar to that of Aber et al. (1954) in that the daily urinary output in severe cases of hypopituitarism may be variable and on occasions exceptionally low: volumes of less than $500 \mathrm{ml}$. a day are common, and Case 5 sometimes did not pass water at all during a twenty-four-hour period. All patients treated with cortisone have had an immediate increase in the urinary volume, which has remained steady at two litres or more a day during treatment. This suggests that the gratifying clinical improvement obtained by treatment with cortisone may be related to changes in water metabolism.

Sheehan and Summers (1952) consider that, despite the relative uniformity of the clinical picture, the episodes of coma which may occur from time to time in hypopituitarism are caused by different types of functional disturbance. Some patients are suffering from severe hypoglycaemia, others from hypothermia, and a few have a large reduction in sodium and chloride levels, possibly caused by an acute adrenal insufficiency or resulting from the preceding attack of vomiting and diarrhoea. To this list we would add water retention as a possible cause of coma and death.

Case 1 was first diagnosed as suffering from hypopituitarism when she was admitted to hospital in coma as an emergency case. She was not hypoglycaemic, and recovered consciousness during the next three days without 
any form of treatment. After the clinical diagnosis had been fully confirmed by numerous investigations (Table I) she was treated with A.C.T.H. at intervals for the next eight months and responded extremely well. On two occasions, however, she developed fairly severe water retention, although the dose of A.C.T.H. which she was receiving at the time was not excessive (40 or $60 \mathrm{mg}$. daily) and she had previously received similar doses for several weeks without untoward effects. We attributed the attacks of water retention to the small quantities of pitressin which we believed some of the early batches of A.C.T.H. contained, and she recovered on each occasion when the A.C.T.H. was stopped for a few days and then changed to another batch. She was discharged from hospital on a maintenance dose of $25 \mathrm{mg}$. daily, but unfortunately she left the area in order to make contact with her husband, from whom she had been separated for several years, and we lost sight of her.

She was readmitted five months later suffering from severe hypopituitarism, and went into coma while we were carrying out a further series of investigations and before any form of treatment was started. During the five days preceding death there was a considerable decrease in the urinary volume and in the serum sodium, which fell from 137 to $116 \mathrm{mEq} / 1$. The serum potassium also fell from 4.6 to $2.9 \mathrm{mEq} / 1$. Urinary studies showed that this was due to water retention and not to urinary lose of electrolytes. There was no decrease in haemoglobin or haematocrit levels in the blood. When she was in coma the blood sugar was $65 \mathrm{mg} . / 100 \mathrm{ml}$. and the rectal temperature dropped to $95^{\circ} \mathrm{F}$. $\left(35^{\circ}\right.$ C.). She looked bloated, and became more so as the depth of the coma increased. Measures to treat the hypothermia raised the rectal temperature to $99^{\circ} \mathrm{F}$. $\left(37.2^{\circ} \mathrm{C}\right.$.), and she was given $125 \mathrm{mg}$. of cortisone intramuscularly on the day before she died.

At necropsy the pituitary gland was found to be considerably reduced in size, weighing $0.21 \mathrm{~g}$., and the thyroid gland, the ovaries, and the uterus were very small. The suprarenals were leaf-like bodies and showed severe atrophy of both cortex and medulla. The atrophy was most noticeable in the cortex, which was reduced to a thickness of some twenty cells. There was marked interstitial oedema in the myocardium, both muscle bundles and individual fibres being separated by free fluid. In the brain the Virchow-Robin spaces were distended with fluid and there was some oedema of the pia arachnoid. There was also moderate interstitial oedema in the medulla of the kidneys though not in the lungs. The pituitary was largely replaced by hyaline and fibrous tissue, only a few groups of parenchymatous cells remaining.

We feel that this case illustrates the danger of the disturbance of water balance that may exist in severe cases of hypopituitarism, and the appropriate treatment would have been to give the patient moderate doses of cortisone before she was moribund. On the other hand, Case 5 drifted into a hypothermic coma while receiving $50 \mathrm{mg}$. of cortisone daily, and recovered after cortisone was stopped and the body warmed. Recovery might have been more certain if we had also injected sodium thyroxine on the lines attempted by Summers (1953) for the treatment of myxoedema coma. In other cases of hypopituitarism the episodes of coma are caused by severe hypoglycaemia, the most effective treatment for which is the administration of intravenous glucose combined with repeated estimations of the blood sugar.

Our experience of six cases of coma encountered during the past few years, and a study of other reports, have emphasized the diversity of the functional disturbance causing the coma and the need for biochemical investigations to be carried out before treatment is started. The administration of cortisone may save life in some cases, especially when there is evidence of water retention, but in coma associated with hypothermia other measures are likely to prove more successful, and measurement of the rectal temperature, if necessary with a bacteriological thermometer, should be included in the clinical examination.

\section{Summary}

The clinical features of nine cases of hypopituitarism and the value of biochemical investigations are discussed.

Treatment with cortisone and thyroid has proved more satisfactory than with A.C.T.H. or cortisone alone. The addition of methyltestosterone is recommended in some cases.

The abnormality of water balance in hypopituitarism is emphasized, and it is suggested that water retention may be one of the causes of coma in this condition.

Our thanks are due to Dr. A. C. Crooke and other physicians who kindly referred patients to us for treatment, and to $\mathrm{Dr}$. D. F. Barrowcliff for the necropsy report on Case 1 .

REFERENCES

Aber, G. M., Chandler, G. N., and Hartfall, S. J. (1954). British Medical Journal, 1, 1 .

Bartter, F. C., Fourman, P., Albright, F., Forbes. A. P., Jeffries, W. M. Griswold, G., Dempsey, E., Bryant, D., and Carroll, E. (1950). J. clin. Invest., $29,950$.

Chalmers, T. M., and Lewis, A. A. G. (1951). Lancet, 2, 1158.

Cooke, R. T., and Sheehan, H. L. (1950). British Medical Journal, 1, 928. Fraser, R. W., and Smith, P. H. (1941). Quart. J. Med., 10, 297.

Hart, F. D. (1953). In Cortisone and A.C.T.H. in Clinical Practice, edited by W. S. C. Copeman. London.

Hubble, D. (1952) Lancet, 1, 1123 .

Knowlton, A. I., Jailer, J. W., Hamilton, H., and West, R. (1950). Amer. J. Med., 8, 269.

Lewis, A. A. G. (1952). Proc. roy. Soc. Med., 45, 63.

Oelbaum, M. H. (1952). British Medical Journal, 2, 110

Oleesky, S. and Stanbury, S. W. (1951), Lancet, 2, 664 .

Prunty, F. T. G. (1953). British Medical Journal, 1, 852

Robertson, J. D. (1951), Lancet, 2, 282.

- and Kirkpatrick, H. F. W. (1951). Ibid., 2,54

Rolland, C. F., and Matthews, J. D. (1952). British Medical Journal, 1 1220

Sheehan, H. L. (1939). Quart. J. Med., 8, 277.

- and Murdoch, R. (1938). Lancet, 2, 132 .

- and Summers, V. K. (1949). Quart. J. Med., 18, 319.

- (1952). British Medical Journal, 1, 1214.

Slessor, A. (1952). Proc. roy. Soc. Med., 45, 67.

Summers, V. K. (1953). British Medical Journal, 2, 366.

and Sheehan, H. L. (1951). Ibid., 2, 564.

\section{OSTEOARTHRITIS AND REST}

BY

F. DUDLEY HART, M.D., F.R.C.P.

Assistant Physician, Westminster Hospital ; Physician, St. Stephen's Hospital, London, S.W.10

MONICA WATKINS, M.B.

Medical Registrar, St. Stephen's Hospital

DENIS BURLEY, M.B.

House-Physician, St. Stephen's Hospital

AND

M. T. RICHARDS, M.B.

House-Physician, St. Stephen's Hospital

Current treatment of osteoarthritis of the weight-bearing joints, if one looks into recent textbooks and articles on the subject, emphasizes the value of rest ; rarely are its hazards even mentioned. The patient is encouraged to become slimmer, less active, and to reduce his activities rather than the reverse. The patients themselves have different views in most cases. Fletcher (1951) states: "Most patients are under the impression that they must use their joints as much as possible, and that if they do not they will become crippled." In Hollander's 5th edition of Comroe's Arthritis we read, "Many individuals suffering from degenerative joint disease are obsessed with the idea that their joints will become stiff unless they exercise them continuously; this is not true." Substitute the word "periodically" for "continuously" and it is perfectly true. Patients get to know their arthritic joints and learn how to live with them. Their statements should not be lightly discarded or dis- 